\title{
ANALISIS PENGARUH PENCARIAN SENSASI DAN LOCUS OF CONTROL TERHADAP PILIHAN KECEPATAN SAAT MENGEMUDI DI JABODETABEK
}

\author{
Alfredo Samuel ${ }^{1}$, Widodo Kushartomo², dan Leksmono Suryo Putranto ${ }^{3}$ \\ ${ }^{1}$ Program Studi Sarjana Teknik Sipil, Universitas Tarumanagara, Jl. Letjen S. Parman No.1 Jakarta \\ alfredo.325150200@stu.untar.ac.id \\ ${ }^{2}$ Program Studi Sarjana Teknik Sipil, Universitas Tarumanagara, J1. Letjen S. Parman No.1 Jakarta \\ widodo@untar.ac.id \\ ${ }^{3}$ Program Studi Sarjana Teknik Sipil, Universitas Tarumanagara, Jl. Letjen S. Parman No.1 Jakarta \\ leksmonop@ft.untar.ac.id
}

Masuk: 08-01-2021, revisi: 03-02-2021, diterima untuk diterbitkan: 04-02-2021

\begin{abstract}
Speed is the amount that indicates the distance traveled by the vehicle divided by the time traveled. Sensationseeking and locus of control play an important role when humans choose speed options while driving. Sensation seeking is a personality tra feature expressed in search of new, varied, complex experiences and intense accompanied by a willingness to take risks in order to feel the experience. Meanwhile, the locus of control is the belief that the individual has about the causes that occur in the life of the individual. This study was conducted to find out how much influence sensation seeking as well as locus of control on a person's driving speed choices and know how much locus of control affects a person when looking for sensation. Data for the study was obtained through an online questionnaire. This research will use Structural Equation Modeling Method or SEM. The results of the study found that sensation seeking is a factor that greatly influences a person's speed choice of 65.61\%, while the locus of control is a factor that slightly affects a person's speed choice of 1.64\%. In addition, the locus of control is quite affecting a person when looking for sensations which is $23.04 \%$.
\end{abstract}

Keywords: Speed; Sensation Seeking; Locus of Control; Speed Options; Structure Equation Modelling.

\begin{abstract}
ABSTRAK
Kecepatan adalah besaran yang menunjukan jarak yang ditempuh kendaraan dibagi waktu yang ditempuh. Pencarian sensasi dan locus of control mempunyai peran penting ketika manusia memilih pilihan kecepatan saat mengemudi. Pencarian sensasi adalah ciri kepribadian yang diekspresikan dalam hal untuk mencari pengalaman baru, bervariasi, kompleks dan intens yang disertai kemauan untuk mengambil risiko agar merasakan pengalaman tersebut. Sedangkan, locus of control adalah keyakinan yang dimiliki individu mengenai penyebab yang terjadi di kehidupan individu tersebut. Penelitian ini dilakukan untuk mengetahui seberapa besar pengaruh pencarian sensasi serta locus of control terhadap pilihan kecepatan mengemudi seseorang dan mengetahui seberapa besar locus of control mempengaruhi seseorang ketika mencari sensasi. Data untuk penelitian didapatkan melalui kuesioner online. Penelitian ini akan menggunakan Metode Structural Equation Modeling atau SEM. Dari hasil penelitian didapatkan bahwa pencarian sensasi merupakan faktor yang sangat mempengaruhi pilihan kecepataan seseorang yaitu sebesar $65,61 \%$, sedangkan locus of control merupakan faktor yang sedikit mempengaruhi pilihan kecepatan seseorang yaitu sebesar 1,64\%. Selain itu, locus of control cukup mempengaruhi seseorang ketika ingin mencari sensasi yaitu sebesar $23,04 \%$.
\end{abstract}

Kata Kunci: Kecepatan; Pencarian Sensasi; Locus of Control; Pilihan Kecepatan; Structure Equation Modelling.

\section{PENDAHULUAN}

Kecelakaan lalu lintas adalah suatu peristiwa di jalan yang tidak diduga dan tidak disengaja melibatkan kendaraan dengan atau tanpa pengguna jalan lain yang mengakitbakan korban manusia dan/atau kerugian harta benda (UndangUndang Republik Indonesia No 22 Tahun 2009 tentang Lalu Lintas dan Angkutan Jalan). Setiap tahunnya diperkirakan 1,2 juta orang tewas dalam kecelakaan lalu lintas jalan, sedangkan jumlah yang terluka mencapai 50 juta orang (WHO, 2014). Maka dari itu, mengemudi merupakan kegiatan yang membutuhkan perhatian penuh dan konsetrasi yang sangat tinggi. Pemilihan kecepatan yang tepat merupakan hal yang sangat penting untuk 
menghindari terjadinya kecelakaan lalu lintas. Salah satu penyebab terjadinya kecelakaan lalu lintas adalah berkendara dengan kecepatan melebihi batas ataupun kurang dari batas sewajarnya (Bacho dkk, 2013). Kecepatan yang dibawah atau diatas batas kecepatan yang sewajarnya dapat dipengaruhi oleh pencarian sensasi. Pencarian sensasi telah diteliti terkait dengan praktik mengemudi berbahaya (Arnett, 1990). Faktor selain pencarian sensasi adalah locus of control yang dimiliki seseorang. Locus of control dapat menggambarkan posisi dan mengetahui seberapa kuat kendali individu untuk mematuhi peraturan lalu lintas, dapat bersumber dari dalam diri atau berasal dari luar diri individu tersebut (Rotter dkk, 1972). Tujuan penelitian ini untuk mengetahui hubungan dan pengaruh antara pencarian sensasi, locus of control, dan kecepatan. Dengan memahami hubungan dan pengaruh antara pencarian sensasi, locus of control dan kecepatan dapat digunakan untuk mengidentifikasi Langkah-langkah teknis yang dapat dilakukan untuk mengendalikan kecepatan saat mengemudi.

\section{Pencarian sensasi}

Pencarian sensasi adalah ciri kepribadian yang diekspersikan dalam kecenderungan umum untuk mencari sensasi dan pengalaman yang bervariasi baru, kompleks, dan intens serta kemauan untuk mengambil risiko demi pengalaman tersebut (Zuckerman, 2007). Pencarian sensasi merupakan faktor yang dapat memprediksi perilaku pelanggaran lalu lintas maka perlu mempertimbangkan pengaruh dari pencarian sensasi dalam usaha mengubah perilaku melanggar lalu lintas menjadi perilaku taat lalu lintas dapat diterapkan lebih efektif (Najeeb, 2011).

\section{Locus of control}

Locus of control adalah sifat kepribadian yang menjelaskan persepsi dari mana individu menentukan penyebab peristiwa-peristiwa dalam hidup (Malik dkk, 2015). Locus of control digolongkan menjadi 2, yaitu locus of control internal dan locus of control eksternal. Individu yang memiliki locus of control internal adalah individu yang mempunyai kepercayaan bahwa dirinya sendiri yang dapat mengendalikan segala hal yang terjadi di hidupnya dan dapat memberi konsekuensi yang akan berdampak pada dirinya (Kreitner \& Kinicki, 2009). Sedangkan, individu yang memiliki locus of control eksternal adalah individu yang memiliki keyakinan bahwa semua hal yang terjadi di hidup individu tersebut merupakan hal yang dikontrol oleh kekuatan luar seperti kekuatan bantuan orang lain, keberuntungan dan kesempatan (Devin dkk, 2013).

\section{Kecepatan}

Kecepatan adalah besaran yang menunujukan jarak yang ditempuh kendaraan dibagi waktu tempuh. Biasanya dinyatakan dalam km/jam (Sukirman, 1999). Julianto (2010), menjelaskan bahwa kecepatan adalah parameter utama selain volume dan kerapatan yan dapat mendefinisikan keadaan arus lalu lintas di suatu jalan. Terdapat 3 macam jenis kecepatan, yaitu kecepatan setempat, kecepatan perjalanan dan kecepatan bergerak. Kecepatan setempat merupakan kecepatan suatu kendaraan yang diukur dari suatu tempat ke tempat yang telah ditentukan. Kecepatan perjalanan adalah kecepatan efektif kendaraan yang sedang dalam perjalanan antara dua tempat. Kecepatan bergerak atau kecepatan rata-rata kendaraan saat bergerak didapatkan dengan cara membagi panjang jalur yang ditempuh dibagi dengan waktu kendaraan bergerak di suatu ruas jalan.

\section{Kecepatan rencana}

Kecepatan rencana adalah kecepatan yang ditentukan untuk perencanaan pada setiap bagian jalan raya seperti untuk merencanakan kemiringan jalan, tikungan, jarak pandang, dan sebagainya. Pada Tabel 1 akan ditampilkan mengenai kecepatan rencana sesuai klasifikasi jalan dikawasan perkotaan.

Tabel 1. Kecepatan Rencana $\left(\mathrm{V}_{\mathrm{R}}\right)$ sesuai klasifikasi jalan di kawasan perkotaan

\begin{tabular}{ccc}
\hline No & Fungsi Jalan & Kecepatan Rencana $\left(\mathrm{V}_{\mathrm{R}}\right)(\mathrm{km} / \mathrm{jam})$ \\
\hline 1 & Arteri Primer & $50-100$ \\
2 & Kolektor Primer & $40-80$ \\
3 & Arteri Sekunder & $50-80$ \\
4 & Kolektor Sekunder & $30-50$ \\
5 & Lokal Sekunder & $30-50$ \\
\hline
\end{tabular}

(Sumber: Standar Geometrik Jalan Perkotaan, Dep. PU, 2004)

\section{METODE PENELITIAN}

Untuk memperoleh data dalam penelitian ini, metode yang digunakan adalah dengan cara penyebaran kuesioner secara online. Penelitian ini dimulai dari identifikasi masalah dan penentuan tujuan dari penelitian ini, lalu dilanjutkan ke tahap studi literatur. Tahap selanjutnya adalah rumusan dan ruang lingkup penelitian. Ruang lingkup dalam penelitian ini diidentifikasikan dalam batasan subjek penelitian, lokasi penelitian dan data penelitian. Batasan seperti responden yang tinggal dan berkegiatan di Jabodetabek dan responden minimal sudah memiliki SIM A. 
Tahapan selanjutnya adalah tahap penyusunan kuesioner. Skala Likert terdiri dari empat pernyataan sikap yaitu Sangat Tidak Sesuai (STS) yang berbobot nilai 1, Tidak Sesuai (TS) yang berbobot nilai 2, Sesuai (S) yang berbobot nilai 3, Sangat Sesuai (SS) yang berbobot nilai 4. Setelah kuesioner disebarkan, akan dilakukan uji validitas dan uji reliabilitas dengan program SPSS untuk mengetahui apakah kuesioner yang telah dibuat dapat dinyatakan valid dan reliabel. Setelah mendapatkan hasil dari uji validitas dan reliabilitas, maka dilakukan perbaikan kalimat pada indikator pertanyaan yang hasilnya tidak valid dan tidak reliabel. Jika sudah melakukan perbaikan, maka kuesioner akan disebar Kembali secara online. Setelah data terkumpul, maka dilakukan analisis data menggunakan program AMOS dengan menggunakan metode Structural Equation Modelling (SEM) dan menentukan kesimpulan dan saran. Berikut diagram alir (flowchart) pada Gambar 1.

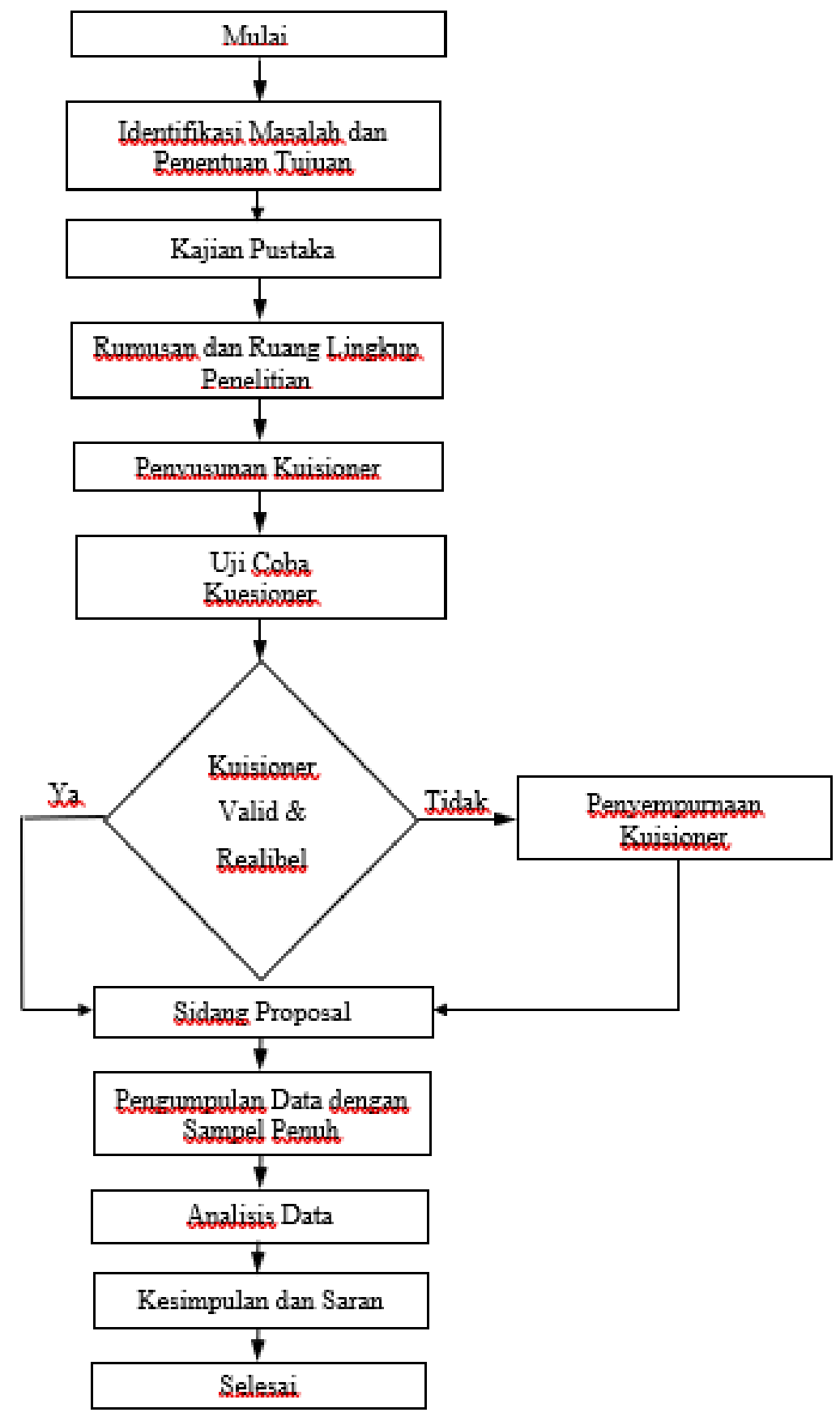

Gambar 1. Diagram alir penelitian 


\section{Structural Equation Modelling}

Pada penelitian ini menggunakan metode Structural Equation Modelling (SEM). Penggunaan SEM bertujuan untuk mengetahui seberapa besar hubungan dan pengaruh antara pencarian sensasi, locus of control dan kecepatan. SEM merupakan teknik analisis multivariat yang dikembangkan guna menutupi keterbatasan yang dimiliki oleh modelmodel analisis sebelumnya yang telah digunakan secara luas dalam penelitian statistik. Model-model analisis yang dimaksud adalah analisis regresi, analisis jalur, dan analisis faktor konfirmatori (Hox \& Bechger, 1998).

\section{HASIL DAN PEMBAHASAN}

Pada tahap perencanaan kuesioner, peneliti menargetkan 150 responden untuk megisi kuesioner yang akan disebarkan. Akan tetapi, pada realisasinya jumlah responden yang didapatkan sebanyak 160 responden dan menggunakan data dari 160 responden yang telah terkumpul. Daftar pertanyaan yang disajikan pada kuesioner akan ditampilkan pada Tabel 2. Terdapat 3 bagian, yaitu pencarian sensasi, locus of control dan pilihan kecepatan saat mengemudi.

Tabel 2. Daftar pertanyaan kuesioner

\begin{tabular}{|c|c|c|}
\hline Bagian & No & Pertanyaan \\
\hline \multirow{8}{*}{$\begin{array}{l}\text { Pencarian } \\
\text { Sensasi }\end{array}$} & a1 & Saya suka melakukan hal-hal yang menakutkan \\
\hline & a2 & Saya suka untuk mencoba melakukan terjun payung \\
\hline & a3 & Saya suka untuk menjelajah ke tempat-tempat baru yang asing bagi saya \\
\hline & a4 & $\begin{array}{l}\text { Saya suka melakukan perjalanan tanpa merencanakan tempat tujuan dan jadwalnya } \\
\text { terlebih dahulu }\end{array}$ \\
\hline & a5 & Saya adalah orang yang suka berpesta dan hura-hura \\
\hline & a6 & $\begin{array}{l}\text { Saya suka untuk melakukan pengalaman baru yang menarik, meskipun saya harus } \\
\text { melawan aturan }\end{array}$ \\
\hline & a7 & Saya tidak suka menghabiskan banyak waktu dirumah \\
\hline & a8 & Saya lebih suka berteman dengan orang yang menarik dan tidak terduga \\
\hline \multirow{10}{*}{$\begin{array}{l}\text { Locus of } \\
\text { Control }\end{array}$} & $\mathrm{c} 1$ & $\begin{array}{l}\text { Saya percaya bahwa ketika saya membuat kesalahan, saya dapat memperbaiki atas } \\
\text { kesalahan yang saya lakukan }\end{array}$ \\
\hline & $\mathrm{c} 2$ & $\begin{array}{l}\text { Saya percaya bahwa cara terbaik untuk menangani masalah adalah dengan tidak } \\
\text { memikirkan masalah tersebut }\end{array}$ \\
\hline & $\mathrm{c} 3$ & Saya percaya bahwa hidup saya ditentukan oleh saya sendiri \\
\hline & $\mathrm{c} 4$ & Saya percaya bahwa saya tidak dapat menentukan apa yang dapat terjadi dihidup saya \\
\hline & $\mathrm{c} 5$ & Ketika saya berusaha untuk melakukan sesuatu, saya pasti mengalami kegagalan \\
\hline & c6 & $\begin{array}{l}\text { Saya tidak percaya jika berusaha keras dalam melakukan sesuatu akan mendapatkan hasil } \\
\text { yang baik }\end{array}$ \\
\hline & c7 & Saya percaya ketika saya berusaha, saya akan mendapatkan hal yang saya inginkan \\
\hline & $\mathrm{c} 8$ & $\begin{array}{l}\text { Saya merasa tidak ada gunanya mencoba sesuatu hal karena saya percaya bahwa saya } \\
\text { tidak lebih pintar dari orang lain }\end{array}$ \\
\hline & c9 & Saya percaya dengan keberuntungan \\
\hline & $\mathrm{c} 10$ & Saya percaya bahwa apa yang terjadi hari ini adalah sesuatu yang tidak disengaja \\
\hline
\end{tabular}


Tabel 2. Daftar pertanyaan kuesioner (Lanjutan)

\begin{tabular}{|c|c|c|}
\hline Bagian & & Pertanyaan \\
\hline \multirow{3}{*}{$\begin{array}{l}\text { Locus of } \\
\text { Control }\end{array}$} & $\mathrm{c} 11$ & Saya percaya lebih baik menjadi beruntung daripada menjadi pintar \\
\hline & $\mathrm{c} 12$ & $\begin{array}{l}\text { Saya adalah orang yang membutuhkan bantuan orang lain ketika mengerjakan } \\
\text { sesuatu }\end{array}$ \\
\hline & $\mathrm{c} 13$ & Sebagian dari hidup saya dipengaruhi oleh orang lain \\
\hline \multirow{4}{*}{$\begin{array}{l}\text { Pilihan } \\
\text { Kecepatan saat } \\
\text { Mengemudi }\end{array}$} & pm1 & Saya sering berkendara dengan kecepatan tinggi ketika jalan sedang sepi \\
\hline & $\mathrm{pm} 2$ & $\begin{array}{l}\text { Saya tidak suka mengemudi dengan kecepatan tinggi ketika melewati kawasan } \\
\text { permukiman }\end{array}$ \\
\hline & pm3 & Saya tidak suka mengemudi dengan kecepatan tinggi di tikungan \\
\hline & $\mathrm{pm} 4$ & Saya sering mengemudi dengan kecepatan tinggi ketika kondisi hujan \\
\hline
\end{tabular}

Responden akan menjawab dengan memilih 4 pilihan jawaban yaitu yaitu Sangat Tidak Sesuai (STS) yang berbobot nilai 1, Tidak Sesuai (TS) yang berbobot nilai 2, Sesuai (S) yang berbobot nilai 3, Sangat Sesuai (SS) yang berbobot nilai 4 dan berkebalikan untuk pertanyaan yg bersifat negatif. Terdapat juga uji validitas dan uji reliabilitas terhadap pertanyaan di kuesioner ini. Berikut hasil dari uji validitas dan uji reliabilitas terhadap kuesioner ini. Hasil uji validitas dapat dilihat pada Tabel 3 dan untuk hasil uji reliabilitas dapat dilihat pada Tabel 4.

Tabel 3.Uji validitas

\begin{tabular}{ccc}
\hline No & & Kriteria \\
\hline a1 & Spearman Method & Valid \\
a2 & Spearman Method & Valid \\
a3 & Spearman Method & Valid \\
a4 & Spearman Method & Valid \\
a5 & Spearman Method & Valid \\
a6 & Spearman Method & Valid \\
a7 & Spearman Method & Valid \\
a8 & Spearman Method & Valid \\
c1 & Spearman Method & Valid \\
c2 & Spearman Method & Valid \\
c3 & Spearman Method & Valid \\
c4 & Spearman Method & Valid \\
c5 & Spearman Method & Valid \\
c6 & Spearman Method & Valid \\
c7 & Spearman Method & Valid \\
c8 & Spearman Method & Valid \\
c9 & Spearman Method & Valid \\
c10 & Spearman Method & Valid \\
c11 & Spearman Method & Valid \\
c12 & Spearman Method & Valid \\
\hline
\end{tabular}


Tabel 3.Uji validitas (lanjutan)

\begin{tabular}{ccc}
\hline No & & Kriteria \\
\hline c13 & Spearman Method & Valid \\
pm1 & Spearman Method & Valid \\
pm2 & Spearman Method & Valid \\
pm3 & Spearman Method & Valid \\
pm4 & Spearman Method & Valid
\end{tabular}

Tabel 4. Uji reliabilitas

\begin{tabular}{|c|c|c|}
\hline & $N$ & Cronbach's Alpha \\
\hline \multicolumn{3}{|l|}{ Pencarian Sensasi } \\
\hline $\begin{array}{l}\text { Keinginan untuk melakukan pengalaman } \\
\text { menegangkan/menyeramkan. }\end{array}$ & 2 & 0,848 \\
\hline $\begin{array}{l}\text { Keinginan untuk melakukan pengalaman } \\
\text { baru. }\end{array}$ & 2 & 0,53 \\
\hline $\begin{array}{l}\text { Keinginan untuk melakukan pengalaman } \\
\text { menyenangkan tetapi berisiko. }\end{array}$ & 2 & 0,802 \\
\hline $\begin{array}{l}\text { Ketidaksukaan untuk melakukan } \\
\text { pengalaman yang berulang. }\end{array}$ & 2 & 0,804 \\
\hline \multicolumn{3}{|l|}{ Locus of Control } \\
\hline Kepercayaan terhadap diri sendiri & 2 & 0,259 \\
\hline Kepercayaan terhadap hasil usaha & 2 & 0,393 \\
\hline Kepercayaan tentang adanya keberuntungan & 2 & 0,436 \\
\hline Ketergantungan akan bantuan orang lain & 2 & 0,556 \\
\hline \multicolumn{3}{|l|}{ Pilihan Kecepatan } \\
\hline Pilihan kecepatan saat mengemudi & 4 & 0,408 \\
\hline
\end{tabular}

Setelah melakukan uji coba validitas dan reliabilitas, maka akan ditampilkan data hasil dari jawaban responden mengenai keinginan untuk melakukan pengalaman menegangkan atau menyeramkan, keinginan untuk melakukan pengalaman baru, keinginan untuk melakukan pengalaman menyenangkan tetapi berisiko, ketidaksukaan untuk melakukan pengalaman yang berulang, kepercayaan terhadap diri sendiri. Data akan ditampilkan pada Tabel 5 hingga Tabel 9. 
Tabel 5. Jumlah data (N), frekuensi dan mean keinginan untuk melakukan pengalaman menegangkan atau menyeramkan

\begin{tabular}{|c|c|c|c|c|c|c|c|}
\hline \multirow{2}{*}{$\mathrm{NO}$} & \multirow{2}{*}{ INDIKATOR } & \multirow{2}{*}{$\mathrm{N}$} & \multicolumn{4}{|c|}{ SKALA } & \multirow{2}{*}{$M E A N$} \\
\hline & & & 1 & 2 & 3 & 4 & \\
\hline 1 & $\begin{array}{l}\text { Saya suka melakukan hal-hal yang } \\
\text { menakutkan }\end{array}$ & 160 & 44 & 64 & 41 & 11 & 2,12 \\
\hline 2 & $\begin{array}{l}\text { Saya suka untuk mencoba } \\
\text { melakukan terjun payung }\end{array}$ & 160 & 64 & 45 & 34 & 17 & 2,03 \\
\hline
\end{tabular}

Tabel 6. Jumlah data $(\mathrm{N})$, frekuensi dan mean keinginan untuk melakukan pengalaman baru

\begin{tabular}{llllllll}
\hline NO & \multicolumn{1}{c}{ INDIKATOR } & N & \multicolumn{4}{c}{ SKALA } & \multirow{2}{*}{ MEAN } \\
\cline { 4 - 6 } 3 & & & 1 & 2 & 3 & 4 & \\
\hline & $\begin{array}{l}\text { Saya suka untuk menjelajah ke } \\
\text { tempat-tempat baru yang asing bagi } \\
\text { saya }\end{array}$ & 160 & 2 & 17 & 57 & 84 & 3,39 \\
$\quad \begin{array}{l}\text { Saya suka melakukan perjalanan } \\
\text { tanpa merencanakan tempat tujuan } \\
\text { dan jadwalnya terlebih dahulu }\end{array}$ & 160 & 30 & 38 & 52 & 40 & 2,64 \\
\hline
\end{tabular}

Tabel 7. Jumlah data (N), frekuensi dan mean keinginan untuk melakukan pengalaman menyenangkan tetapi berisiko

\begin{tabular}{|c|c|c|c|c|c|c|c|}
\hline \multirow[t]{2}{*}{$\mathrm{NO}$} & \multirow[t]{2}{*}{ INDIKATOR } & \multirow[t]{2}{*}{$\mathrm{N}$} & \multicolumn{4}{|c|}{ SKALA } & \multirow{2}{*}{$M E A N$} \\
\hline & & & 1 & 2 & 3 & 4 & \\
\hline 5 & $\begin{array}{l}\text { Saya adalah orang yang suka } \\
\text { berpesta dan hura-hura }\end{array}$ & 160 & 70 & 47 & 34 & 9 & 1,89 \\
\hline 6 & $\begin{array}{l}\text { Saya suka untuk melakukan } \\
\text { pengalaman baru yang menarik } \\
\text { meskipun saya harus melawan } \\
\text { aturan }\end{array}$ & 160 & 49 & 53 & 36 & 22 & 2,19 \\
\hline
\end{tabular}

Tabel 8. Jumlah data $(\mathrm{N})$, frekuensi dan mean keinginan untuk melakukan pengalaman melakukan pengalaman yang berulang

\begin{tabular}{clcccccc}
\hline NO & \multicolumn{1}{c}{ INDIKATOR } & N & \multicolumn{4}{c}{ SKALA } & \multirow{2}{*}{ MEAN } \\
\cline { 3 - 6 } & & 160 & 33 & 63 & 41 & 23 & 2,34 \\
\hline 7 & $\begin{array}{l}\text { Saya tidak suka menghabiskan } \\
\text { banyak waktu dirumah }\end{array}$ & & & & & & \\
8 & $\begin{array}{l}\text { Saya lebih suka berteman dengan } \\
\text { orang yang menarik dan tidak } \\
\text { terduga }\end{array}$ & 160 & 7 & 48 & 62 & 43 & 2,88 \\
\hline
\end{tabular}

Tabel 9. Jumlah data (N), frekuensi dan mean kepercayaan terhadap diri sendiri

\begin{tabular}{|c|c|c|c|c|c|c|c|}
\hline \multirow[t]{2}{*}{$\mathrm{NO}$} & \multirow[t]{2}{*}{ INDIKATOR } & \multirow[t]{2}{*}{$\mathrm{N}$} & \multicolumn{4}{|c|}{ SKALA } & \multirow{2}{*}{ MEAN } \\
\hline & & & 1 & 2 & 3 & 4 & \\
\hline 9 & $\begin{array}{l}\text { Saya percaya bahwa ketika saya } \\
\text { membuat kesalahan, saya mampu } \\
\text { memperbaikinya }\end{array}$ & 160 & 81 & 71 & 8 & - & 1,54 \\
\hline
\end{tabular}


Tabel 9. Jumlah data $(\mathrm{N})$, frekuensi dan mean kepercayaan terhadap diri sendiri (Lanjutan)

\begin{tabular}{|c|c|c|c|c|c|c|c|}
\hline \multirow[t]{2}{*}{$\mathrm{NO}$} & \multirow[t]{2}{*}{ INDIKATOR } & \multirow[t]{2}{*}{$\mathrm{N}$} & \multicolumn{4}{|c|}{ SKALA } & \multirow{2}{*}{$M E A N$} \\
\hline & & & 1 & 2 & 3 & 4 & \\
\hline 10 & $\begin{array}{l}\text { Saya percaya bahwa cara terbaik } \\
\text { untuk menangani masalah adalah } \\
\text { dengan tidak memikirkan masalah } \\
\text { tersebut }\end{array}$ & 160 & 62 & 58 & 27 & 13 & 1,94 \\
\hline 11 & $\begin{array}{l}\text { Saya percaya bahwa hidup saya } \\
\text { ditentukan oleh saya sendiri }\end{array}$ & 160 & 81 & 56 & 17 & 6 & 1,68 \\
\hline 12 & $\begin{array}{l}\text { Saya tidak dapat menentukan apa } \\
\text { yang terjadi di hidup saya }\end{array}$ & 160 & 39 & 65 & 37 & 19 & 2,24 \\
\hline
\end{tabular}

Untuk hasil jawaban responden mengenai kepercayaan terhadap diri sendiri, kepercayaan terhadap hasil usaha, kepercayaan tentang adanya keberuntungan, ketergantungan akan bantuan orang lain, pilihan kecepatan saat mengemudi (dampak langsung) dan pilihan kecepatan saat mengemudi (tidak berdampak langsung) akan ditampilkan pada Tabel 10 hingga Tabel 14.

Tabel 10. Jumlah data $(\mathrm{N})$, frekuensi dan mean kepercayaan terhadap hasil usaha

\begin{tabular}{|c|c|c|c|c|c|c|c|}
\hline \multirow[t]{2}{*}{$\mathrm{NO}$} & \multirow[t]{2}{*}{ INDIKATOR } & \multirow[t]{2}{*}{$\mathrm{N}$} & \multicolumn{4}{|c|}{ SKALA } & \multirow{2}{*}{ MEAN } \\
\hline & & & 1 & 2 & 3 & 4 & \\
\hline 13 & $\begin{array}{l}\text { Saya sering mengalami kegagalan } \\
\text { ketika saya berusaha mendapatkan } \\
\text { sesuatu }\end{array}$ & 160 & 15 & 68 & 55 & 22 & 2,53 \\
\hline 14 & $\begin{array}{l}\text { Saya tidak percaya jika berusaha } \\
\text { keras dalam melakukan sesuatu } \\
\text { akan mendapatkan hasil yang baik }\end{array}$ & 160 & 102 & 31 & 14 & 13 & 1,61 \\
\hline 15 & $\begin{array}{l}\text { Ketika saya berusaha, saya akan } \\
\text { mendapatkan hal yang saya } \\
\text { inginkan }\end{array}$ & 160 & 99 & 56 & 4 & 1 & 1,42 \\
\hline 16 & $\begin{array}{l}\text { Saya enggan mencoba sesuatu } \\
\text { karena orang lain lebih pandai dari } \\
\text { saya }\end{array}$ & 160 & 72 & 66 & 20 & 2 & 1,7 \\
\hline
\end{tabular}

Tabel 11. Jumlah data $(\mathrm{N})$, frekuensi dan mean kepercayaan tentang adanya keberuntungan

\begin{tabular}{|c|c|c|c|c|c|c|c|}
\hline \multirow[t]{2}{*}{$\mathrm{NO}$} & \multirow[t]{2}{*}{ INDIKATOR } & \multirow[t]{2}{*}{$\mathrm{N}$} & \multicolumn{4}{|c|}{ SKALA } & \multirow{2}{*}{ MEAN } \\
\hline & & & 1 & 2 & 3 & 4 & \\
\hline 17 & $\begin{array}{l}\text { Saya percaya dengan } \\
\text { keberuntungan }\end{array}$ & 160 & 3 & 30 & 66 & 61 & 3,16 \\
\hline 18 & $\begin{array}{l}\text { Saya percaya bahwa apa yang } \\
\text { terjadi hari ini adalah sesuatu yang } \\
\text { tidak disengaja }\end{array}$ & 160 & 27 & 63 & 48 & 22 & 2,41 \\
\hline 19 & $\begin{array}{l}\text { Saya percaya lebih baik menjadi } \\
\text { beruntung daripada menjadi pintar }\end{array}$ & 160 & 27 & 63 & 39 & 31 & 2,46 \\
\hline
\end{tabular}

Tabel 12. Jumlah data (N), frekuensi dan mean ketergantungan akan bantuan orang lain

\begin{tabular}{llllllll}
\hline NO & \multicolumn{1}{c}{ INDIKATOR } & N & \multicolumn{4}{c}{ SKALA } & \multirow{2}{*}{ MEAN } \\
\cline { 3 - 5 } 20 & $\begin{array}{l}\text { Saya adalah orang yang } \\
\text { membutuhkan bantuan orang lain } \\
\text { ketika mengerjakan sesuatu }\end{array}$ & 160 & 10 & 58 & 74 & 18 & 2,63 \\
\multirow{2}{2}{21} & $\begin{array}{l}\text { Sebagian dari hidup saya } \\
\text { dipengaruhi oleh orang lain }\end{array}$ & 160 & 23 & 63 & 52 & 22 & 2,46 \\
\hline
\end{tabular}


Tabel 13. Jumlah data $(\mathrm{N})$, frekuensi dan mean pilihan kecepatan saat mengemudi (dampak langsung)

\begin{tabular}{clcccccc}
\hline NO & \multicolumn{1}{c}{ INDIKATOR } & N & \multicolumn{4}{c}{ SKALA } & \multirow{2}{*}{ MEAN } \\
\cline { 3 - 5 } 22 & $\begin{array}{l}\text { Saya mengemudi dengan kecepatan } \\
\text { tinggi ketika jalan sedang sepi. }\end{array}$ & 160 & 9 & 24 & 82 & 45 & 3,02 \\
$\begin{array}{l}\text { Saya tidak suka mengemudi dengan } \\
\text { kecepatan tinggi ketika melewati } \\
\text { kawasan permukiman }\end{array}$ & 160 & 91 & 44 & 14 & 11 & 1,66 \\
\hline
\end{tabular}

Tabel 14. Jumlah data (N), frekuensi dan mean pilihan kecepatan saat mengemudi (dampak tidak

\begin{tabular}{|c|c|c|c|c|c|c|c|}
\hline & & $\frac{\text { sung) }}{\mathrm{N}}$ & \multicolumn{4}{|c|}{ SKALA } & \\
\hline $\mathrm{NO}$ & INDIKATOR & $\mathrm{N}$ & 1 & $\frac{N \pi}{2}$ & $\frac{\mathrm{LA}}{3}$ & 4 & $M E A N$ \\
\hline 23 & $\begin{array}{l}\text { Saya mengemudi dengan kecepatan } \\
\text { tinggi ketika hujan }\end{array}$ & 160 & 76 & 65 & 15 & 4 & 1,67 \\
\hline 24 & $\begin{array}{l}\text { Saya tidak suka mengemudi dengan } \\
\text { kecepatan tinggi di tikungan }\end{array}$ & 160 & 86 & 38 & 27 & 9 & 1,74 \\
\hline
\end{tabular}

Dapat dilihat pada Tabel 13 menunjukan bahwa responden memiliki pilihan untuk mengemudi dengan kecepatan tinggi saat kondisi jalan sedang sepi. Selain itu, tingkat pencarian sensasi seseorang meningkat ketika seseorang menjelajah atau pergi ke tempat asing bagi dirinya.

Setelah mengetahui hasil data survei, maka akan dilakukan analisis dengan menggunakan data yang telah terkumpul penuh menggunakan metode Structural Equation Modelling (SEM) dengan program AMOS. Gambar 2 merupakan model SEM yang digunakan dan hasil koefisien jalur yang berguna untuk mengetahui seberapa besar hubungan antara pencarian sensasi dan locus of control terhadap pilihan kecepatan saat mengemudi.

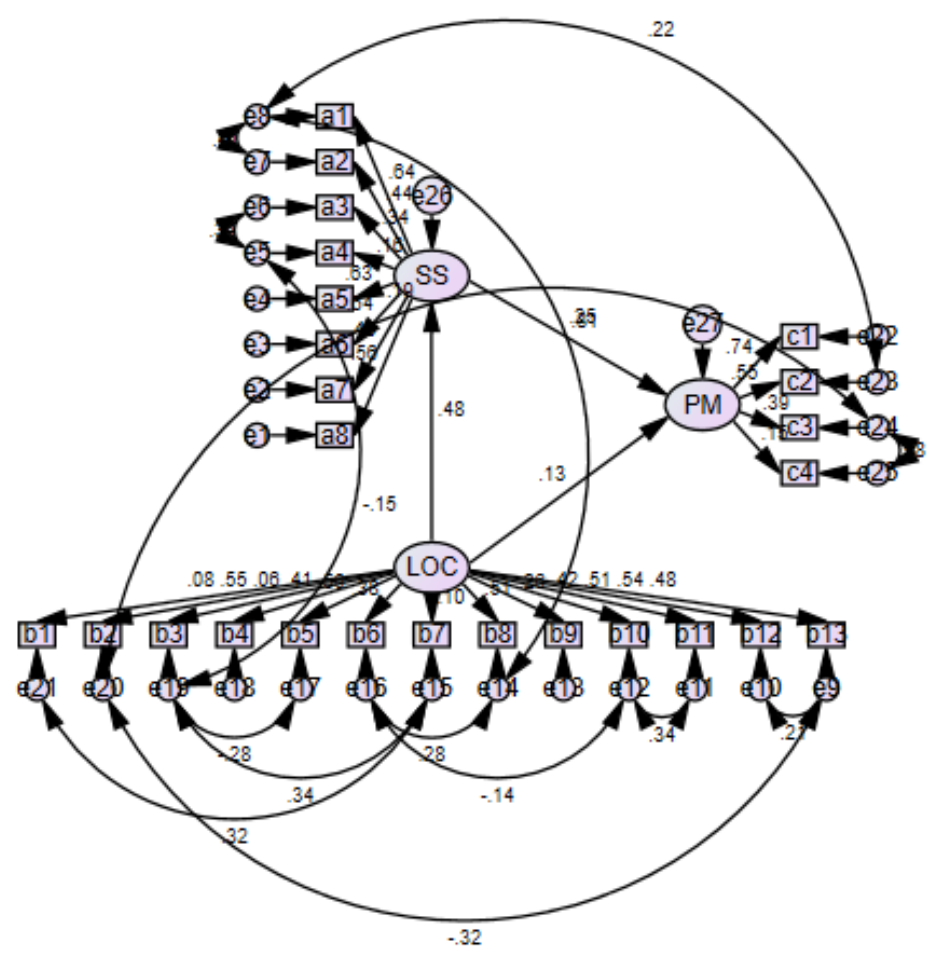

Gambar 2. Structural Equation Modelling

Hasil koefisien jalur dari model SEM dari data keseluruhan dapat dilihat pada Tabel 15 dan untuk pengaruh antar indicator dengan variabel dapat dilihat pada Tabel 16. 
Tabel 15. Hasil koefisien jalur dari model SEM data keseluruhan

\begin{tabular}{cc}
\hline Hubungan & Persentase \\
\hline Locus of Control $\rightarrow$ Pencarian Sensasi & $23,04 \%$ \\
Pencarian Sensasi $\rightarrow$ Pilihan Kecepatan saat Mengemudi & $65,61 \%$ \\
Locus of Control $\rightarrow$ Pilihan Kecepatan saat Mengemudi & $1,69 \%$ \\
\hline
\end{tabular}

Tabel 16. Pengaruh indikator terhadap variabel model modifikasi ke-1 data keseluruhan

\begin{tabular}{|c|c|c|c|}
\hline KELOMPOK & INDIKATOR & $\mathrm{P}$ & SIGNIFIKAN? \\
\hline \multirow{8}{*}{ Pencarian Sensasi } & $\mathrm{a} 1$ & $<0,001$ & $\mathrm{Ya}$ \\
\hline & $\mathrm{a} 2$ & $<0,001$ & $\mathrm{Ya}$ \\
\hline & a3 & $<0,001$ & $\mathrm{Ya}$ \\
\hline & a4 & 0,025 & $\mathrm{Ya}$ \\
\hline & a5 & $<0,001$ & $\mathrm{Ya}$ \\
\hline & a6 & $<0,001$ & $\mathrm{Ya}$ \\
\hline & a7 & $<0,001$ & $\mathrm{Ya}$ \\
\hline & a8 & $<0,001$ & $\mathrm{Ya}$ \\
\hline \multirow{13}{*}{ Locus of Control } & b1 & 0,365 & Tidak \\
\hline & b2 & $<0,001$ & $\mathrm{Ya}$ \\
\hline & b3 & 0,520 & Tidak \\
\hline & b4 & $<0,001$ & $\mathrm{Ya}$ \\
\hline & b5 & $<0,001$ & $\mathrm{Ya}$ \\
\hline & b6 & $<0,001$ & $\mathrm{Ya}$ \\
\hline & b7 & 0,272 & Tidak \\
\hline & b8 & $<0,001$ & $\mathrm{Ya}$ \\
\hline & b9 & 0,01 & $\mathrm{Ya}$ \\
\hline & b10 & $<0,001$ & $\mathrm{Ya}$ \\
\hline & b11 & $<0,001$ & $\mathrm{Ya}$ \\
\hline & b12 & $<0,001$ & $\mathrm{Ya}$ \\
\hline & b13 & $<0,001$ & $\mathrm{Ya}$ \\
\hline \multirow{4}{*}{$\begin{array}{l}\text { Pilihan Kecepatan } \\
\text { saat Mengemudi }\end{array}$} & $\mathrm{c} 1$ & $<0,001$ & $\mathrm{Ya}$ \\
\hline & $\mathrm{c} 2$ & $<0,001$ & $\mathrm{Ya}$ \\
\hline & c3 & $<0,001$ & $\mathrm{Ya}$ \\
\hline & $\mathrm{c} 4$ & 0,092 & Tidak \\
\hline Pencarian Sensasi & $\begin{array}{c}\text { Locus of } \\
\text { Control }\end{array}$ & $<0,001$ & $\mathrm{Ya}$ \\
\hline \multirow{2}{*}{$\begin{array}{l}\text { Pilihan Kecepatan } \\
\text { saat Mengemudi }\end{array}$} & $\begin{array}{c}\text { Pencarian } \\
\text { Sensasi }\end{array}$ & $<0,001$ & $\mathrm{Ya}$ \\
\hline & $\begin{array}{c}\text { Locus of } \\
\text { Control }\end{array}$ & 0,248 & Tidak \\
\hline
\end{tabular}

Berdasarkan Tabel 15 dapat dilihat bahwa locus of control memiliki pengaruh yang tidak terlalu besar terhadap pencarian sensasi dan locus of control memiliki pengaruh yang sangat kecil terhadap pilihan kecepatan saat mengemudi. Di sisi lain, pencarian sensasi memiliki pengaruh yang sangat besar terhadap pilihan kecepatan saat mengemudi. Maka didapatkan hasil bahwa pencarian sensasi merupakan faktor yang paling berpengaruh terhadap pilihan kecepatan seseorang saat mengemudi. Sedangkan, locus of control berpengaruh tetapi memiliki presentasi yang sangat kecil. Berdasarkan Tabel 16 dapat dilihat bahwa indikator pada bagian locus of control dan 1 indikator pada bagian mengemudi dengan kecepatan tinggi yang memiliki nilai signifikansi diatas 0,05 sehingga indikatorindikator tersebut tidak berpengaruh signifikan terhadap variabelnya. Tabel 16 menujukan juga bahwa variabel locus of control tidak berpengaruh signifikan terhadap pilihan kecepatan saat mengemudi. Tingkat pencarian sensasi yang dimiliki seseorang secara signifikan dapat mempengaruhi pilihan kecepatan saat mengemudi (Bachoo dkk, 2013)

\section{KESIMPULAN DAN SARAN}

\section{Kesimpulan}

Berdasarkan penelitian yang telah dilakukan dapat disimpulkan sebagai berikut: 
1. Berdasarkan data keseluruhan yang dianalisis dengan metode SEM, locus of control mempengaruhi pencarian sensasi sebesar 23,04\%. Maka, locus of control yang dimiliki seseorang memiliki pengaruh tetapi tidak berpengaruh besar terhadap tingkat pencarian sensasi seseorang.

2. Berdasarkan data keseluruhan yang didapatkan dari metode SEM, pencarian sensasi mempengaruhi pilihan kecepatan saat mengemudi sebesar 65,61\%. Maka, tingkat pencarian yang dimiliki seseorang sangat berpengaruh terhadap pilihan kecepatan saat mengemudi.

3. Berdasarkan data keseluruhan yang didapatkan dari metode SEM, locus of control mempengaruhi pilihan kecepatan saat mengemudi sebesar 1,69\%. Maka, tingkat locus of control yang dimiliki seseorang memiliki pengaruh yang sangat kecil terhadap pilihan kecepatan saat mengemudi.

4. Berdasarkan dari data yang didapatkan dari kuesioner, responden memiliki kecenderungan untuk berkecepatan tinggi saat kondisi jalan sedang sepi (rataan=3,02).

\section{Saran}

Berdasarkan penelitian yang sudah dilakukan dapat direkomendasikan saran terhadap penelitian selanjutnya, yakni:

1. Penelitian ini dapat dimanfaatkan sebagai pertimbangan dalam perencanaan prasarana dan sarana untuk melakukan intervensi terhadap kecepatan, terlebih untuk jalan-jalan yang sepi, misalnya dengan memasang speed hump dan rambu kurangi kecepatan.

2. Khusus untuk pengemudi pria dan dewasa muda perlu ada upaya sosialisasi untuk mengurangi kecepatan saat jalan-jalan sepi.

3. Dilakukan penyebaran kuisioner secara langsung (offline) juga dikarenakan terdapat responden yang kurang memahami pertanyaan yang ada pada kuisioner secara online sehingga responden memberi respon yang kurang baik.

4. Model dari SEM sebaiknya dirancang sedemikian rupa dan sudah dirancang bersamaan dengan perencanaan kuisioner untuk mendapatkan model yang lebih baik.

\section{DAFTAR PUSTAKA}

Arnett, J. "Drunk driving, sensation seeking, and egocentrism among adolescents." Personality and Individual Differences, vol. 11, 1990, pp. 541-546.

Bachoo, S., et al. "The influence of anger, impulsivity, sensation seeking and driver attitudes on risky driving behaviour among post-graduate university students in Durban, South Africa." Accident Analysis and Prevention, vol. 5, 2013, pp. 67-76.

Devin, Hassan Fahin, et al. "Comparative and Correlative Study of Locus of Control, Assertiveness, Mental Health Status in Active and Non-Active Elderly People". Bulletin of the Georgian National Academy of Sciences, vol. 7, 2013.

Hox, J.J., Bechger, T.M. “An Introduction to Structural Equation Modeling”. Family Science Review, vol. 11, 1998. pp. 354-373.

Kreitner, Kinicki. Perilaku Organisasi. Jakarta : Salemba Empat, 2009.

Malik, M.A., et al. "Rewards and employee creative performance: Moderating effects of creative self-efficacy, reward importance, and locus of control.” Journal of Organizational Behavior, vol. 36, 2015, pp. 59-74.

Najeeb, P. M. "A Study of the Psychological Factors that Influence the rule Violation Behaviour of Drivers.” Paper Presented at the International Co-operation on Theories and Concepts in Traffic Safety, 25thICTCT Workshop, 2011.

Rotter, J.B., et al. Application of a social learning theory of pesonality. New York: Holt Rinehart and Winston, 1972.

Sukirman, S. Dasar-Dasar Perencanaan Geometrik Jalan. Bandung: NOVA, 1999.

Undang-Undang Republik Indonesia No 22 Tahun 2009 tentang Lalu Lintas dan Angkutan Jalan.

WHO. World Report on Road Traffic Injury Prevetion. Geneva: World Health Organization, 2014.

Zuckerman, M. Sensation seeking and risky behavior. Washington DC: American Psychological Association, 2007. 
